\title{
Routines in the process of organizational evolution
}

Professor Ewa Stańczyk-Hugiet Wroclaw University of Economics Department of Strategy and Management Methods
In our evolutionary theory, these routines play the role that genes play in biological evolutionary theory.

Nelson and Winter 1982, 14

\section{Introduction}

The research on changes constitutes the proof of not exhausting the subject and the real scope of explored problems. In many papers the further directions of research are indicated. Pettigrew (1987) formulated some first advice for researchers. He regarded that proper theory of changes had to realize the following tasks: a) to simultaneously explain stabilizing forces and changing ones, b) to acknowledge and include exogenous and endogenous sources of changes in considerations, as well as c) to connect phenomena at the micro- and macro level of an analysis, and finally d) to take into consideration the compatibility of problems due to the degree and direction of changes. Additionally, researchers ought to accept constant uncertainty of understanding and making theory about changes and to assume that their work constitutes the continued interpretation and consideration about the context, the process and the content of a change and about the ability to regulate relationships amongst these three issues. 
According to A.H. Van de Ven (1987, p. 331), a strong theory of a change ought to explain the following issues: a) how a structure and individual, intentional actions are connected at the micro- and macro level of an analysis, b) how a change is produced by both internal functioning of a structure and external individual intentional actions, c) how stability, instability, and time could be included as a clue historical measure.

In general, the paper presented is embedded into researching changes, yet taking into account evolutionary ontology and epistemology what is not present in Polish research and is not significantly developed in the world science. An evolutionary approach allows to understand changes from another perspective - selection is a dominant mechanism.

Evolutionary theory of change suggests the concept of routines seems to fulfil the prerequisites required of a unit of analysis in an evolutionary framework. Thus, the goal of the paper is to outline a cognitive framework of organizational evolution including routines ${ }^{1}$ as a basic construct of the evolutionary theory of the firm.

\section{Organizational evolution}

An evolutionary paradigm is mainly connected with Darwin's work and with the theory of natural selection. It has been adapted to economic science, in which the attention is paid to the dynamics and mechanisms of development, and considerations concerning optimization are out of interests.

It seems that evolutionary logic is best explained by D. Campbell (1960, pp. 380-400) (1969, pp. 69-85), who introduced an evolutionary model VSR (variation-selection-retention), in which variation leads to multiply elements. The second element (stage) - selection - results in a failure or a success. It ought to be emphasized that the success of an organization is identified with not categories of effectiveness, yet with categories of adaptation, survival, and best adjustment. The last stage - retention- means that organizations are able to identify selected deviation that increases the feasibility of survival. D. Campbell argues that the VSR process is the only one useful model explaining evolution and providing observable facts.

1 Acc. to Nelson and Winter (1982, p. 14) routine is treated as a pattern of behaviour that is followed repeatedly. 
A dynamic evolutionary process is described sequentially (Andersen 1994, pp. 102-107):

1. The characteristics of an organization determine its activities in the relationships with the environment (input and output).

2. Facing with exogenous variables influences the effectiveness of an organization.

3. The effectiveness of an organization has the influence on the possibilities of expansion and taking competitive actions towards the other enterprises.

4 . The process creates a dynamic change and the same routines applied to the new conditions generate different results. Additionally, there is also the mutation of decisional roles. After each iteration an organization gets new process routines that enable to improve the characteristics of an organization as well as works out investment routines for the subsequent iteration.

5. The processes of selection and variation makes an organization evolve. The condition of a sector at a particular time suggests the feasibility of survival in the forthcoming period.

Such perceiving the process of evolution suggests that the processes of variation and selection are connected each other. In general, variation is the response to the problems created by selective environment.

An extremely salient element of an evolutionary debate is the role of organizational and interorganizational routines since routines attend not only to variation via their replication, yet they constitute an important element of retention mechanisms.

\section{Routines as the subject of organizational evolution}

It becomes necessary to ascertain the subject of selection on the grounds of the fact that evolutionary logic mainly explains changes in the categories of selection. Consequently, a very salient issue embedded in the field of exploring selection processes is the concern about the subject of selection.

R. Nelson and S. Winter's ascertainments are significantly salient in strategic management, especially in the area of explaining mechanisms of adaptation and the focus are organizational routines and their variation ensuring survival.

A traditional approach to an organization even withstood routines. As for a new approach, routines might be located at various levels as well as they lead, direct behavior, influence the pursuit of discovering novelties, sustain the features of an organism, and determine possible behavior (similarly to environment).

R. Nelson and S. Winter took into consideration a dynamic approach to an institution and to development having been represented by J. Schumpeter. For 
that purpose they used theory of an organization and the category of dynamic equilibrium. The authors also were interested in the elements of evolutionary theory of an enterprise - routine patterns of organizational behavior. Additionally, institutional and organizational limitations between enterprises and environment are created by maximizing the advantages of developing such routine behavior. Due to that approach, an organization is a derivative of a set of routine behavior and environment.

According to R. Nelson and S. Winter (1982), the units of selection are routines and competences and their diffusion determines selection and, as a result, the survival or death of an organization. By contrast, R. Dawkins (1976) regards that routines and competences are provided with a selfish gene that reveals in a hypothesis that routines and competences do not take care of an organization and the organization lives so long that it is necessary for promoting routines (retention, alternatively replication). R. Dawkins has implemented the notion 'meme' - equivalent to 'gene' constituting an autonomic unit that is replicated by imitation, and is the subject to replication and mutation as well. On the other hand, if the assumptions concerning epistasis are made, it is not possible to regard that routines remain isolated. Independently on epistemological perspective, selection is connected with achieved results and their subjects are routines and competences - no matter if the thesis of their isolation is accepted or it is accepted that they function in connection with the context (StanczykHugiet 2013, pp. 159-160).

The way in which routines and competences reveal in actions is significantly important in the process of selection. It is worth emphasizing once again that R. Nelson and S. Winter in a year 1982 unequivocally indicated routines (procedures) as suitable for being a subject of selection. Thus, in contrary to H. Aldrich (1999), not organizations are those objects, yet routines. As for that concept, the knowledge about routines is the core of understanding behavior.

Later, in a year 2006, H. Aldrich and M. Ruef outlined some advice for researching evolution. It was suggested that the research on evolution inside an organization should concern strategic initiatives, roles connected with the work, and the rules of administering. As a result, an organization becomes the connection of competences and routines. As for that perspective, the process of evolution concerns the process of changes at every level and it occurs as a result of selecting characters described by routines and competences. Consequently, an organization is treated as a temporal deposit of competences and routines that are retained by organization's members and rooted in their technologies, 
tangible artefacts, structures and other displays. Spreading competences and routines depends on selective survival and growth of an organization what happens by competences and routines' combination.

According to the authors, the subject of the analysis (and therefore selection), might be as follows (Aldrich, Ruef 2006, p. 28):

- routines and competences in an organization,

- organizations as the whole,

- populations of organizations or communities.

Consequently, in accordance with that approach, multi-level research of evolution processes is proposed and including routines into considerations is a result of Winter and Nelson's work. Routines could be interpreted, acc. to Becker (2004, pp. 643-677), as regular behavior, cognitive regularities, and proclivities. Behavior is referred to a recursive pattern of interactions amongst participants and the accent is on collective and observable nature of routines. Cognitive regularities mean rules and standards of operating procedures on which employees function and cooperate. Routines as proclivities liberate behavior and cognitive regularities as well as emphasize on random nature of routines. Routines are then treated as a pattern of repeatable regular behavior found rather in stories than during observation.

Concluding, the mechanism of variation refers mainly to organizational and interorganizational routines. By contrast, the processes of selection concern an organization and consequently mainly organizations constitute the subject of selection. According to the considerations in the context of routines and competences, an organization is regarded as a unique idiosyncratic set of routines and competences. Such understanding an organization means that routines and competences are developed or die when the organization is developed or dies. This way, the selection of an organization is the same what the selection of routines.

\section{Routines in the process of evolution}

The mechanism of selection is significant in evolutionary processes. Consequently, R. Nelson and S. Winter propose an evolutionary model of a sector in which the mechanism of selection is based on the set of routines, as the equivalent to biological genes, which constitute patterns of enterprises' behavior for various types of activities (i.e. procedures). As for the patterns, the selection does not have to result in (moreover, it does not result) choosing enterprises maximizing profits. Companies so as to increase profits seek new

11

EWA STAŃCZYK-HUGIET 
techniques to make innovations or imitation and, in this way, to modify a set of their routines.

According to a relational approach, the category of competitive advantage is strictly connected with the network of relationships in which an organization is embedded and consequently determined by idiosyncratic interorganizational relationships (Dyer, Singh 1998, pp. 660-679). Continuing the arguments in a relational logic, organizational resources, that are core for surviving, are the potential for extending boundaries of an organization and they are embedded in interorganizational routines and processes. A relational rent - in other words, competitive advantage resulting from exchange relationships, occurs when partners invest in relational resources, develop interorganizational routines of sharing knowledge, when they effectively use the mechanisms of coordination, and when they exploit complementary resources and capabilities (Dyer, Singh 1998, pp. 660-679).

The process of developing a set of routine patterns of behavior in an organization is stochastic. Under the influence of that process, an organization evolutionarily changes its boundaries on the market. Routine patterns of behavior are active and redundant and their system during the interaction with environment undergoes mutation, recombination, transition, and transposition (Noga 2009, p. 179). Nevertheless, it does not mean that seeking new patterns is foregone. Additionally, in comparison with a classic approach, they are not even the source of inertia.

Evolutionary dynamics means that over time the behavior patterns of an organization change. It is explained by self-conditioning path dependence.

R. Nelson and S. Winter, emphasizing a central role of routine behavior, regard that decision makers have to function in the realities at any given time taking into consideration the uncertainty. Due to evolutionary economics, business entities are regarded as those which reduce uncertainty and aim at attaining business goals according to the particular set of rules. Additionally, as for evolutionary economics, searching/varying routines is a deliberate process, in which seeking better ways of actions aims at improving future results of an organization (Nelson 1995, pp. 48-90; Zollo, Winter 2002, pp. 339 -351).

J. Strużyna (2012, pp. 209 - 210) proposes a very interesting interpretation (in the model of an evolving organization) of Nelson and Winter's ideas (compare: (Stańczyk-Hugiet 2012b, pp. 11-15)). According to the J. Strużyna, effectiveness in an evolutionary approach fluctuates around organizational routine behavior. A set of routines in a given organization or extending a pattern of routines in various organizations constitutes a baseline for effectiveness that is a result of 
random changes of various routines what limits the importance of a conscious choice. The role of a manager is similar to other factors determining routines and the effectiveness concept. Routines are the antecedents of the effectiveness concept, and a desirable point is achieved only in favorable circumstances.

\section{Types of routines}

R. Nelson and S. Winter reject the issue of maximizing effects of behavior. Routines (a core notion for the author's early theory) influence striving for seeking novelties, underpin the characteristics of an organism, and determine their possible behavior (similarly to environment). Current behavior through the mechanism that is similar to inheritance determines tomorrow's behavior.

Routines are much more than regular, predictable business behavior. In details, they also constitute constant proclivities and strategic heuristics that create an enterprise's attitude to not routine problems. Thus, three types of routines are very salient:

- operational routines (they manage short-term behavior),

- generic routines (they determine changes in enterprise's capital from one period to another up to the amounts in which currently located behavior is in accordance with a predictable pattern and changes the relationships between subsequent enterprise's states),

- search routines, which modify in time various aspects of operating characteristics (directional rules) and finally lead to innovations and radical changes.

Directional routines, routines changing a process are modelled as research and exploration. They create a characteristic of population (set) of routines' modification or new routines that might be found. The enterprise's policy of searching could be described as a function of the number of variables and the level of probability of distributing those routines that have been found.

The notion 'routines' and its meaning introduced by $\mathrm{R}$. Nelson and S. Winter is much more wider understood than a colloquial phrase 'routines'. Colloquially, development activities of an organization are not associated with routines. However, due to the proposed analysis, those activities include their own routines. The notion 'routines' is used by the authors in a very flexible way, similarly to the notion 'procedures' or 'programs'. Routines might be also referred either to the repeatable pattern of activities in organizations, or to an individual capability as well as they could describe continuous, not disturbed efficacy of such organizational or individual functioning. 
As for those considerations, routines have been formed as a way of adjusting both to environment and to conflicts of interests of organization's members. Being a basic of organizational memory, they are simultaneously its foundation and justification. Information collected in the memory must be confirmed by not only the action (a routine one), yet it also should convict that the conditions giving chances for actions will be properly created through using collected information (knowledge). Likewise, routines not only ease conflicts of interests as they do not lead to highlight them, but also convict that conflicts will not destroy the conditions for activities useful for an individual. Routines having been checked in previous periods are the beginning for the next contracts between the sides of distinct, and in many cases divergent interests (employee - employer).

Taking into account those assumptions, routines might be considered as the subject of interest of all organizational objects. Establishing and sustaining routines give a chance to effective actions, reliable planning, controlling, iteration, and even imitation. It also develops the base for setting goals and tasks in a stable or changing situation since stability is not the state necessarily liberated by routines. Organizations full of routines are not the objects repeating activities previously made ad infinitum. They are open for changes and they also create changes in environment. Organizational routines considered as abstractive ways of functioning might be regarded as a stable order (a goal), however, only in the situation when a stable set of changing resources is imposed. Routines do not exist in a vacuum, and the resources are not unchangeable. Consequently, they have to be created in a suitable relationship. Some of tasks independently become routines. Others are connected with ad hoc efforts to solve problems. Both parts of tasks (routine and ad hoc) may lead to failures if the environment does not cooperate with organizational members. The large parts of problems connected with controlling result from the diversity (inhomogeneity) of environment contribution in an organization. Nevertheless, changes occur and are accumulated.

So as to understand the idea of routines, it is necessary to recognize essential character of automatic repeatability and to take into consideration their five features: (Dosi, Nelson, Winter 2000):

- routines must be the element of organizational memory; they create accumulated redundancy of organizational knowledge ensuring continuous functioning of enterprise's operations,

- routines represent the type of behavior goals, the means for experiencing social control significantly connected with effectively manipulating inputs and signals of environment, which are more or less heterogeneous; continuous 
course of an organization causes that routines are flexible enough for internalizing main changes during performing and continuously removing them,

- routines must be replicable (transferred from one place to another in the same organization),

- it might be expected that effective routines will be imitated (despite some costs of learning) and transferred from one context to another,

- routines are equivalent to intentions (they give a chance) of truce between conflict interests.

Routines in an enterprise could be divided into (Noga 2009, pp. 179):

- technical routines that allow to produce,

- marketing routines that allow to get the best resources and to sell them,

- investment routines that allow to create new producing capacity,

- diversification routines allowing to compete,

- tacit and idiosyncratic knowledge and

- innovative changes.

A. Noga (2009, pp 179-180) contends that routines are active and redundant (latent). Routines interacting with environment are the subject of:

- mutation (innovations, new routines are created),

- recombination (imitation of competitors' routines, including them into active routines),

- transition (imitating competitors, including them into excessive routines),

- transposition (including excessive routines into the active ones).

It is worth emphasizing once again that the process of developing a set of routines is not deterministic, but stochastic. In the end, a change in a set of routines causes that enterprises exist or bankrupt.

\section{Routines from the perspective of inter-organizational cooperation}

Accepting assumptions of evolutionists and current findings in a relational approach (RV), it must be unambiguously acknowledged that in the group of organizational routines a relational capability and networking competence are significantly salient (compare: Czakon 2012, pp. 159-171). Interorganizational relationships as routine behavior of an organization enable adaptation, integration, internal and external reconfiguration of capabilities, resources, or functional competences. Consequently, a set of relationships enables to adapt and to survive in the environment that makes selection (Stańczyk-Hugiet 2013, p. 109). Routines' variation refers to the relationship and the goal is to search

81

EWA STAŃCZYK-HUGIET 
routines ensuring survival. As for that approach, the processes of routines' variation are directed to the relationship of inter-organizational cooperation. The effect of evolution is that organizations are naturally oriented towards cooperation and towards obtaining results of a positive-sum game (Polowczyk, 2010, pp. 493-522) since cooperation extends the development possibilities through creating more differential environment.

Variation is also determined by a set of routines possessed, idiosyncratic learning, and a set of unique resources. Interorganizational relationships are also important for variation processes. Organizations are entities endowed with genes oriented to cooperativeness. Paradoxically, selfish instincts incline to cooperation. Relationships alone do not induce management structure in the network of interorganizational relationships, yet the configuration of relationships induces both mutual adaptation of entities being in the relationships and relational skills and capabilities of each organization.

Not only is mutual adaptation salient. More important is the fact that adaptation to environment occurs through the network of interorganizational relationships. The emergence of new forms automatically creates environment independently whether it has the form of minimal emergence, diachronic emergence, or synchronic one ${ }^{2}$ (Harper, Endres 2012, pp. 352-367).

Variation means not only generating novelties. The process of variation also happens on the path towards the replication of even effective routines.

R. Brennan (2006, pp. 829-838) believes that evolutionary perspective should take into account the assumptions that interorganizational routines (not intraorganizational ones) are significantly important in the process of evolution.

Taking into considerations above issues, the subject of cognition are so-called co-evolving dynamics, analyzed by J.P. Murmann (2003), that need interaction amongst many elements. Both macro co-evolution and micro co-evolution (that occurs inside an organization) ought to be considered. Additionally, it concerns the co-evolution of intraorganizational routines, dynamic capabilities and competences in the intraorganizational competitive context.

2 Minimal emergence equals material realization, coherence, and non-distributivity and structure-dependence of system properties; diachronic emergence means minimal emergence plus novelty and unpredictability; synchronic emergence means minimal emergence plus irreducibility (compare.: Stańczyk-Hugiet E. (2012a, s. 9-17). 


\section{Directions of researching routines}

Despite the clarity of the concept, the problem of routines is not unequivocally solved. G. M. Hodgson (2003, pp. 355-384) thoroughly and creatively criticized the notion of routines. He suggests, by contrast to the assumptions of Nelson and Winter, that the roots of their concept might be associated with Darwin's theory, which (similarly to "Evolutionary theory of economic change") discusses about variation, retention, and selection. Additionally, he regards that the concept of organization's evolution is much more than a biological analogy. For instance, the variation results from seeking in routines more efficient practice of selection and it does not refer, in the case of an organization, only to the issues of birth and death, yet it concerns also transforming objects from the former to latter. Acknowledging Darwin's roots, what in the light of Nelson and Winter's declaration about the connection of their concept with Lamarck's concept is not so obvious or is omission, emerges some interpretation problems. Consequently, it is necessary to closer look at a unit and the process, especially at a replicator and replication, ontology and similarity of both theories as well as at epistemology.

The research published by C. Salvato (2009, pp. 68-102) allowed to check accidental and intentional changes and to identify a repertoire of evolving routines. The research also verified important issues in the enterprise's events. The regularities discovered in the way of using optimal adjustment revealed a different image of processes in an enterprise than it was exemplary described in documents. In details:

- routines evolve in accordance with various patterns that go hand in hand with various combination of actions and cognition, experiments, and logically structured considerations,

- that what is called the recombination of routines results from a conscious managerial intervention directed to the replication of mutations that previously delivered a positive feedback of internal or external selecting forces; managerial activities incorporate the awareness of adaptively searching the results of recombining routines,

- the recombination of routines includes significant adaptive potential resulting from both information from routines' mutation and intentional replication. Consequently, appropriate stimuli are necessary for managers.

That research explicitly proves that routines ought to be explored in the connection with adaptation - not with effectiveness due to a classic economic approach. Thus, it becomes necessary to clarify the category of adaptation and 
to indicate various types of adaptation. It seems that a set of the following main six profiles of adjusting an organization proposed by N. Venkatraman (1989, pp. 423-444) might be helpful: deviation, mediation, moderation, shape (originally: 'gestalts' understood as internal cohesiveness amongst attributes), covariance, adjustment. Each of that profile indicates a different way of organization's behavior towards environment and it might be assumed that the behavior is determined by organizational routines.

Taking into account above considerations and arguments, a basic cognitive model of organizational evolution taking into consideration organizational routines has been proposed in the paper (figure 1).

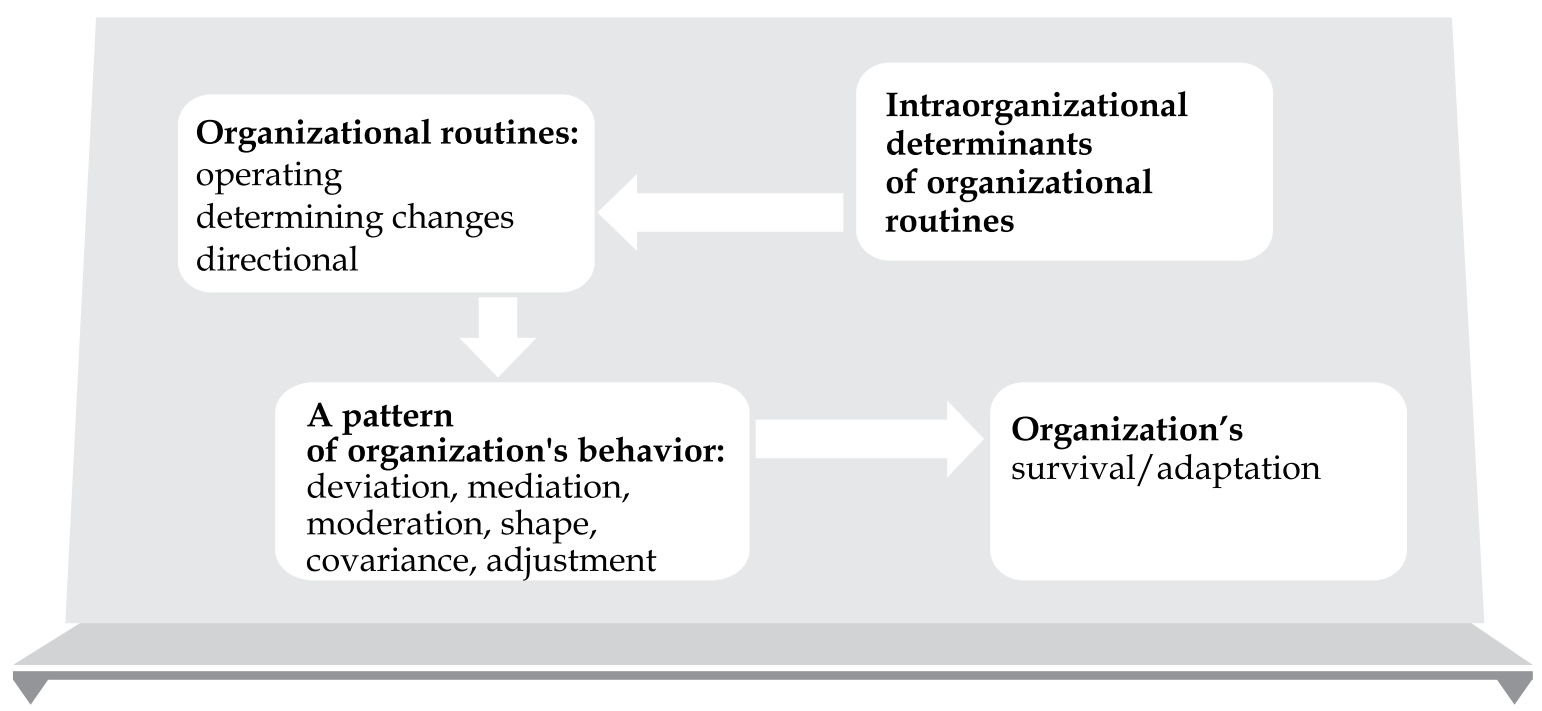

Figure 1. A cognitive model of organizational evolution

Source: own study

The model, apart from organizational routines, includes intraorganizational determinants of developing routines. Apparently, cognition could be considered beyond the boundaries of an organization and then it is necessary to recognize both endogenous and exogenous determinants of organizational routines. The proposed model of recognizing and researching routines is the base for operationalizing particular model's variables what might allow to formulate research hypotheses and to conduct further research in that scope $\mathrm{s}^{3}$.

3 This research was supported by a grant financed by the National Center of Science, decision number DEC-2013/11/B/HS4/00647. 


\section{Conclusion}

Concluding considerations included in the paper, it ought to be emphasized that researching organizational evolution conducted in terms of evolutionary epistemology requires special research attentiveness and consequence. Understanding such mechanisms of evolution like variation, selection, and retention becomes significantly important. Additionally, establishing the object of evolution is also salient. The routines constitute that object. A change of routines' set causes that an organization is able to survive or not. Routines reside in an organization and so as to understand their dynamics it is important to research determinants of routines, especially at the intraorganizational level.

\section{Summary}

\section{Routines in the process of organizational evolution}

The purpose of this article is to outline the cognitive model of organizational evolution taking into account the routines. Organizational evolution requires explanation and understanding of the mechanisms of development: variation, selection and retention. It is necessary also to define the object of evolution. The research results show that organizational routines constitute that object. As for the research purposes, it is important to determine the types of organizational routines. The logic of Nelson and Winter presents that routines appear as operating, generic, and search ones. As a result of the findings in the article, a cognitive model of organizational evolution has been proposed, in which organizational routines are the objects that affect the pattern of organization's behavior and consequently its effectiveness, which in evolutionary terms is manifested by organization's survival.

Key words: evolution, routines, change, variation, selection.

\section{Streszczenie}

\section{Rutyny w procesie organizacyjnej ewolucji}

Celem artykułu jest zarysowanie modelu poznania organizacyjnej ewolucji uwzględniającego rutyny. Organizacyjna ewolucja wymaga wyjaśnienia i zrozumienia mechanizmów rozwoju, czyli różnicowania, selekcji i retencji. Koniecznym jest także określenie obiektu ewolucji. Z badań wynika, że tym obiektem są 
organizacyjne rutyny. Dla badań ważne jest ustalenie rodzajów rutyn organizacyjnych. Z logiki Nelsona i Wintera wynika, że rutyny przejawiają się jako rutyny operacyjne, generyczne i tzw. search. W efekcie ustaleń poczynionych w artykule zaproponowano model poznania organizacyjnej ewolucji, w którym rutyny organizacyjne są obiektami wpływającymi na wzorzec zachowania organizacji, a tym samym jej efektywność, która w ujeciu ewolucyjnym przejawia się przyżyciem organizacji.

\section{Słowa}

kluczowe: ewolucja, rutyny, zmiana, różnicowanie, selekcja.

\section{References}

1. Aldrich H. (1999), Organizations evolving, Sage, London.

2. Aldrich H. Ruef M. (2006), Organizations evolving, Sage, London.

3. Andersen E. S. (1994), Evolutionary economics: Post-Schumpeterian contributions, Pinter, London.

4. Becker M. C. (2004), Organizational routines: A review of literature, "Industrial and Corporate Change", vol. 13, no. 4.

5. Brennan R. (2006), Evolutionary economics and the markets-as-networks approach, "Industrial Marketing Management" 2006, no. 35.

6. Campbell D.T. (1960), Variation and selective retention in creative thought as in other knowledge process, "Psychological Review" vol. 67.

7. Campbell D.T. (1969), Variation and selective retention in sociocultural evolution, "General System", vol. 14.

8. Czakon W., (2012), Sieci w zarzadzaniu strategicznym, Wolters Kluwer, Warszawa.

9. Dawkins R. (1976), The selfish gene, Oxford University Press, New York.

10. Dosi G., Nelson R.R., Winter S.G. (red) (2000), The nature and dynamics of organizational capabilities, Oxford University Press, Oxford.

11. Dyer J. H., Singh H. (1998), The relational view: cooperative strategy and sources of interorganizational competitive advantage, "Academy of Management Review", vol. 23, no. 4.

12. Harper D.A., Endres A.M. (2012), The anatomy of emergence, with a focus upon capital formation, "Journal of Economic Behavior \& Organization", no. 82.

13. Hodgson G.M. (2003), The mystery of the routine. The Darwinian destiny of an evolutionary theory of economic change, "Revue économique", vol. 54, no. 2.

14. Murmann J.P. (2003), Knowledge Competitive Advantage: The Coevolution of Firms, Technology, and National Institutions, Cambridge University Press, Cambridge. 
15. Nelson R. R., Winter S. G. (1982), An Evolutionary Theory of Economic Change, Belknap Press, Cambridge.

16. Nelson R.R. (1995), Recent Evolutionary Theorizing About Economic Change, "Journal of Economic Literature", vol. 33, no. 1.

17. Noga A. (2009), Teorie przedsiębiorstwa [Theories of an enterprise], PWE, Warszawa.

18. Pettigrew A. (1987), The management strategic change, Basil Blackwell, Oxford.

19. Polowczyk J. (2010), Elementy ekonomii behawioralnej w dzietach Adama Smitha [Elements of behavioral economics in the work of A. Smith], "Ekonomista", no. 4.

20. Salvato C. (2003), The role of micro-strategies in the engineering of form evolution, "Journal of Management Studies", vol. 40, no. 1.

21. Stańczyk-Hugiet E. (2012a), Ewolucjonizm, emergentyzm $i$ relacje międzyorganizacyjne, Zmiana warunkiem sukcesu. Współczesne trendy i przeobrażenia metod i praktyk zarządzania w przedsiębiorstwach, Prace Naukowe UE nr 275; G. Bełz, Ł. Wawrzynek eds..

22. Stańczyk-Hugiet E. (2012b), Heterodoksja ewolucyjna a zarządzanie [Evolutionary heterodoxy and management], „Przegląd Organizacji” no. 10.

23. Stańczyk-Hugiet E. (2013), Dynamika strategiczna w ujęciu ewolucyjnym [A strategic dynamics in an evolutionary approach], Wyd. Uniwersytetu Ekonomicznego we Wrocławiu [The publisher of Wroclaw University of Economics], Wrocław.

24. Strużyna J. (2012), Efektywność organizacji w cieniu rutyn [Effectiveness of an organization under the shadow of routines], "Organizacja i Kierowanie", no. 1A.

25. Van de Ven A.H. (1987), Review essay: four Requirements for Processual Analysis, w: A.M. Pettigrew (ed.): The management of strategic change, Blackwell, Oxford.

26. Venkatraman N. (1989), The Concept of Fit in Strategy Research: Toward Verbal and Statistical Correspondence, "The Academy of Management Review", Vol. 14, No. 3.

27. Zollo M., Winter S. G. (2002), Deliberate Learning and the Evolution of Dynamic Capabilities, "Organization Science”, vol. 13, no. 3. 